\title{
Mosquitoes (Diptera, Culicidae) inhabiting foliar tanks of Guzmania brasiliensis Ule (Bromeliaceae) in central Amazonia, Brazil
}

\author{
Sharlene Roberta da Silva Torreias ${ }^{1}$, Ruth Leila Ferreira-Keppler ${ }^{1}$, Bruno Spacek Godoy $^{2}$ \& Neusa Hamada ${ }^{1}$
}

'Coordenação de Pesquisas em Entomologia, Instituto Nacional de Pesquisas da Amazônia, Caixa Postal 478, 69011-970 Manaus-AM, Brazil. rtorreias@ gmail.com; ruth@inpa.gov.br; nhamada@inpa.gov.br

${ }^{2}$ Laboratório de Análise e Gerenciamento Ambiental de Recursos Hídricos, Instituto de Ciências Biológicas, Universidade Federal de Goiás, Caixa Postal 131,74001-970 Goiânia-GO, Brazil. bspacek@gmail.com

\begin{abstract}
Mosquitoes (Diptera, Culicidae) inhabiting foliar tanks of Guzmania brasiliensis Ule (Bromeliaceae) in central Amazonia, Brazil. Mosquitoes in the family Culicidae develop their immature forms in different environments depending on various circumstances. This study represents the first contribution to the ecological knowledge of culicids living in the bromeliad $G$. brasiliensis. The objectives of the study were to compare the Culicidae fauna of bromeliads in two seasonal periods, analyzing their abundance, richness and the influence of $\mathrm{pH}$, conductivity and water volume, on the populations. Sampling was done at Reserva Adolpho Ducke, Manaus, Amazonas, Brazil between 2003 and 2005. Six samplings were done in the rainy season and six in the dry season. On each sampling day, six terrestrial and six epiphytic bromeliads, totaling 144 sampling units, were retrieved. A total of 444 immature mosquitoes were collected, distributed in the following species: Culex (Microculex) stonei Lane \& Whitman, Culex (Microculex) chryselatus Dyar \& Knab, Culex (Microculex) sp., Wyeomyia (Hystatomyia) autocratica Dyar \& Knab and Wyeomyia (Hystatomyia) splendida Bonne-Wepster \& Bonne. The relationship between abundance of Culicidae and sampling period was not significant, although abundance was higher in the dry period. There were significant correlations between water volume and the abundance $(\mathrm{p}=0.003)$ and richness $(\mathrm{p}=0.001)$ of culicids. The $\mathrm{pH}$ was positively related to the occurrence of the species $W y$. autocratica $(\mathrm{p}=0.010)$ and Wy. splendida $(\mathrm{p}=0.006)$, demonstrating the influence of this factor in the structuring of bromeliadinhabiting communities.
\end{abstract}

KEYWORDS. Amazon; Aquatic insects; Culex (Microculex); Phytotelmata; Wyeomyia.

RESUMO. Mosquitos (Diptera, Culicidae) habitando tanques foliares de Guzmania brasiliensis Ule (Bromeliaceae) na Amazônia Central, Brasil. Mosquitos da família Culicidae desenvolvem suas formas imaturas em vários ambientes na dependência de circunstâncias diversas. Este trabalho representa a primeira contribuição ao conhecimento ecológico de culicídeos em $G$. brasiliensis e tem como objetivo inventariar os imaturos em bromélias em dois períodos sazonais, analisando a abundância, riqueza e a influência das variáveis abióticas $\mathrm{pH}$, condutividade e volume de água sobre as populações de Culicidae. Foram realizadas coletas na Reserva Adolpho Ducke, Manaus, Amazonas, Brasil entre 2003 e 2005. Seis coletas foram realizadas no período chuvoso e seis na estação seca. Em cada amostragem, seis bromélias terrestres e seis epífitas foram coletadas, totalizando 144 unidades amostrais. Um total de 444 imaturos foi coletado, distribuídos nas seguintes espécies: Culex (Microculex) stonei Lane \& Whitman, Culex (Microculex) chryselatus Dyar \& Knab, Culex (Microculex) sp., Wyeomyia (Hystatomyia) autocratica Dyar \& Knab e Wyeomyia (Hystatomyia) splendida Bonne-Wepster \& Bonne. A relação entre abundância de Culicidae e períodos não foi significativa, entretanto, o período seco apresentou maior representatividade de imaturos. Houve significância na relação do volume de água e abundância $(\mathrm{p}=0,003)$ e riqueza $(\mathrm{p}=0,001)$ de culicídeos. $\mathrm{O} \mathrm{pH}$ foi o único parâmetro relacionado positivamente com a ocorrência das espécies Wy. autocratica $(\mathrm{p}=0,010)$ e Wy. splendida $(\mathrm{p}=0,006)$ ressaltando a influência deste fator na estruturação das comunidades bromelícolas.

PALAVRAS-CHAVE. Amazônia; Culex (Microculex); Fitotelmata; Insetos aquáticos; Wyeomyia.

Plants in the family Bromeliaceae are essentially neotropical, consisting of approximately 3086 species distributed among 57 genera (Nara \& Weber 2002). In the south and south-east regions of Brazil, the Atlantic Forest has the greatest generic diversity of this family due to the high degree of endemism and the interaction of the diversity of bromeliads with the fauna that inhabit them (Kaehler et al. 2005). In the Amazon, 64 bromeliad species are known to occur, distributed into 14 genera (Smith 1955); these are reported in a variety of different habitats (Ribeiro et al. 1999).

Rainwater and organic resources incorporated through the debris that fall into the axils of bromeliads are essential factors in the bromeliaceous system (Kitching 2000). Bromeliads are considered to be a permanent habitat that is favorable to the colonization of a diverse insect fauna, with Diptera being well represented (Frank 1983). Once the foliar tanks are established, the colonization and maintenance of aquatic organisms is possible by means of ecological processes such as dispersion, colonization and interaction between species (Richardson et al. 2000), resulting in a complex food chain (Laessle 1961; Kitching 2000; Ambruster et al. 2002).

Culicids are common in this type of habitat (Frank \& Lounibos 1983; Müller \& Marcondes 2006, 2007; Liria 2007). In Brazil, interest in phytotelmata began with studies on Anopheles Meigen and on species of epidemiological interest in the subgenus Kerteszia Theobald (Veloso et al. 1956; Aragão 1968a, b) associated with bromeliads in the genera 
Vriesea Lindley, Aechmea Ruiz \& Pavón and Nidularium Lem. (Kitching 2000; Forattini 2002; Müller \& Marcondes 2007).

In the Amazon, knowledge of the culicid fauna in bromeliads is scarce due to the vast geographical extension of the area, the great diversity of habitats and the lack of researchers focused on studies of phytotelmata, among other factors.

Information based on the conservation of natural resources can be used both for the preservation of species and to control of diseases transmitted by mosquitoes. In the Central Amazon, this study represents the first contribution to the knowledge of mosquitoes associated with leaf axils of Guzmania brasiliensis Ule, 1907. The objectives were: to survey the fauna of immature Culicidae in epiphytic and terrestrial bromeliads; to compare the abundance of Culicidae in two seasonal periods (rainy and dry); and to determine whether there is correlation between $\mathrm{pH}$, conductivity, temperature, and volume of the water and the mosquito species associated with bromeliads.

\section{MATERIAL AND METHODS}

Study Area - The study was conducted in the Reserva

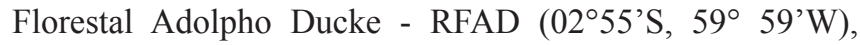
located at $\mathrm{km} 26$ of the State Highway AM 010. This Reserve has an area of $100 \mathrm{~km}^{2}$ and belongs to the Instituto Nacional de Pesquisas da Amazônia (INPA). The vegetation is "terra firme" (not seasonally flooded) forest (Pires 1974), composed of different habitats that may be recognized as plateau, slope, campinarana (white-sand scrub forest) and valley bottoms (Ribeiro et al. 1999). This area is still well preserved and is not completely isolated from the continuous forest. However, it is environmentally threatened by increasing human occupation at its edges (Ribeiro et al. 1999).

Samples were taken in areas of campinarana, which has as its main characteristics, soil composed of white sand and large accumulation of litter, partially closed canopy (with trees between 15 and $25 \mathrm{~m}$ tall), high incidence of light and few large trees (Ribeiro et al. 1999).

The phytotelmata species studied was G. brasiliensis (Fig. 1), which is widely distributed throughout the Amazonian region (Leme 1993). This species has long leaves with acute apices and small red enlarged foliar sheaths that allow formation of water reservoirs. This bromeliad is abundant in the Reserva Ducke, occurring mainly in valley bottoms (baixadas) and in campinarana areas (Ribeiro et al. 1999).

Data Collection - A total of 12 samplings were collected, six in the rainy season (April, May and June 2003, March 2004; March and April and 2005) and six in the dry season (August, September and October 2003/2004) (Ribeiro \& Adis 1984) (the data collection during rainy season was slightly altered due to logistical issues).

In each month, 12 bromeliads, six terrestrial and six epiphytic located between 1 and $3 \mathrm{~m}$ above the ground, were sampled, resulting in 144 sampling units analyzed. The following physical and chemical variables of the water in the tank of each bromeliad were measured: $\mathrm{pH}$, electrical conductivity $(\mu \mathrm{S} / \mathrm{cm})$, temperature $\left({ }^{\circ} \mathrm{C}\right)$ and volume $(\mathrm{mL})$. Data on precipitation were obtained from the Embrapa Western Amazon experimental station, Manaus, Amazonas, located at $\mathrm{km} 30$ on the AM 010 Highway.

In the laboratory, larvae were kept alive and fed until they attained adulthood. Species identifications were based on morphological characters using the keys by Rozeboom \& Komp (1950), Lane (1953a, b), Forattini (1965a, b), Forattini \& Toda (1966), Forattini (2002) and Motta et al. (2007).

Data analysis - The relationship of water volume to the community of immature Culicidae was observed using two regressions: 1) a simple regression between the number of culicids and volume of water $(\mathrm{mL})$ and 2) a multiple regression where species richness was related to the volume of water and the total abundance of individuals. As in the first regression, the residuals did not have homocedasticity of variance. The abundance values were transformed using $\mathrm{Ln}$ $(\mathrm{x}+1)($ Zar 1996).

The " $\mathrm{t}$ " test was used to check the influence of seasonal periods on the abundance of culicids. Logistic regressions were conducted with all species found in order to observe which factors were related to their occurrence. Variables used included $\mathrm{pH}$, temperature and conductivity. These physical and chemical parameters were chosen because they are strongly associated with the amount of nutrients in aquatic systems (Yanoviak 2001).

\section{RESULTS AND DISCUSSION}

A total of 444 immature Culicidae were collected. Of these, 308 were collected in the dry season and 136 in the rainy season. These Culicidae belong to the tribes Culicini and Sabethini represented by Culex (Microculex) stonei (43.7\%), Culex (Microculex) chryselatus $11.7 \%$ and Culex (Microculex) sp. 1 (2\%), Wyeomyia (Hystatomyia) autocratica (21.8\%) and Wyeomyia (Hystatomyia) splendida (20.7\%).

Epiphytic and terrestrial bromeliads - Table I shows the spatial distribution in relation to the richness and abundance of the species present, demonstrating, in a general way, that the number of immatures in the two strata and in the different months sampled was small, suggesting there is little variation of amplitude in their occurrence (between 1 and $3 \mathrm{~m}$ ). The exception was Culex (Microculex) sp., which in May (rainy period) only occurred in epiphytic bromeliads, and in August (dry period) occurred in both strata. $C x$. (Mcx.) chryselatus occurred mainly in the dry season and was found in both strata. These differences may have been caused due to the fact that strata would probably be better viewed if the tanks were checked monthly and in other seasonal periods, or the low abundancy of these taxa during the collecting data period.

Mestre et al. (2001), working in the southern Brazilian state of Paraná, reported that macroinvertebrate communities in the bromeliad Vriesea inflata Wawra, 1883 did not show significant differences between epiphytic and terrestrial strata in terms of abundance and richness of taxa. Yanoviak (1999) working in Panama with populations of Culicidae in tree holes that were vertically stratified (between 10 and $20 \mathrm{~m}$ ) attributed a decline in the abundance of culicids to factors unrelated to 


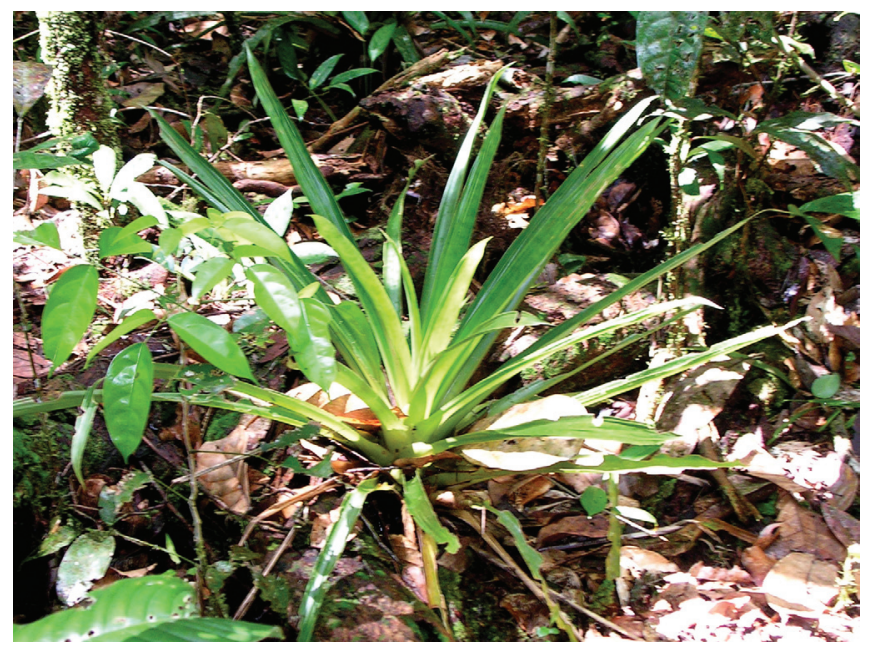

Fig. 1. The terrestrial bromeliad Guzmania brasiliensis in Reserva Ducke, Manaus, Brazil.

the different strata; the decline was attributed to factors such as lack of physiological tolerance of the organisms present, predation and especially the availability of food resources.

The culicid fauna of in G. brasiliensis was composed of species commonly found in bromeliads and in other phytotelmata (Machado-Allison et al. 1986; Forattini 2002; Müller \& Marcondes 2007). According to Forattini (2002), there is evidence of association of mosquitoes with certain plants. The subgenus Microculex Theobald (Table I) was the most abundant. According to Silva et al. (2004) and Müller \& Marcondes (2006), the immature forms are specialized in colonizing this environment, taking into account the availability of ideal conditions for procreation and development of larvae. A large group of culicids also inhabits tree holes, internodes of bamboo and inflorescences of Heliconia L. (Machado-Allison et al. 1986; Sunahara et al. 2002). They also inhabit the axils of Mauritia flexuosa L., 1782 (Arecaceae), where they are part of a complex food chain as prey for top predators, such as Odonata, and where their abundance is significant related to factors such as the volume of water present in the leaf axils (Neiss 2007).

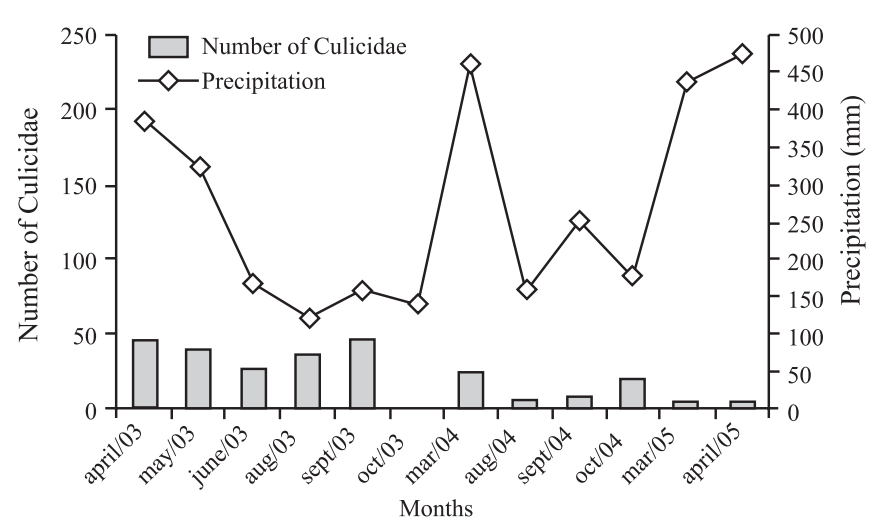

Fig. 2. Precipitation and abundance of immatures of Culicidae collected in Guzmania brasiliensis in the dry and wet periods in 2003 and 2005 in Reserva Ducke, Manaus, Brazil.
Three Culex species were collected in the present study, with $C x$. stonei standing out as the most abundant. These species are well distributed in the Neotropical region (Clastrier 1970; Navarro 1998). Cx. stonei was collected in Vriesea splendens (Brongn.) Lem. 1850, in Venezuela, it is a homoplasic species, as demonstrated through parsimony endemicity analysis, and has a simultaneous distribution, being found on Cerro Copey Island and in Bolivar state in the Gran Savana and Auyan-Tepui National Parks in Venezuelan Guyana (regions that border on Brazil) (Navarro et al. 2007).

In the Brazilian Amazon, $C x$. stonei and $C x$. chryselatus have been observed in terrestrial and epiphytic bromeliads in the states of Pará, Amapá and Amazonas (Cerqueira 1961, Forattini \& Toda 1966), besides in axils of M. flexuosa (Neiss 2007) and in epiphytic species of Vriesea splitgerberi (Mez.), 1953 (Torreias 2008). In southern Brazil they are found in the axils of Nidularium innocentii Lem., 1855 (Bromeliaceae), but there is no record there of the species collected in the present study. However, Culex (Microculex) constituted almost the entire sample; nine species were found, of which $C x$. albipes Lutz was the most abundant (Müller \& Marcondes 2007).

Wy. (Hys.) autocratica and Wy. (Hys.) splendida identified in this study using the taxonomic classification proposed by Judd (1998). Wyeomyia autocratica and Wy. splendida appear to be restricted to developing in bromeliads (Judd 1998). In the Amazon, Cerqueira (1961) reports Wy. autocratica in Manaus, Amazonas, in four localities in the state of Pará and in Cuiabá, Mato Grosso, where the larvae were found at the base of leaves of Bromeliaceae and adults were caught with human bait in the woods during the day. It is well known that Wy. autocratica is both diurnal and sylvatic (Forattini 2002). This species usually feeds on small mammals and birds and on human beings if present in the forest, mainly at dusk (Consoli \& Lourenço-de-Oliveira 1994; Forattini 2002).

Influence of dry and rainy periods in abundance of Culicidae - The highest rate of rainfall occurred in March 2004 (Fig. 2). Although not statistically significant, the data

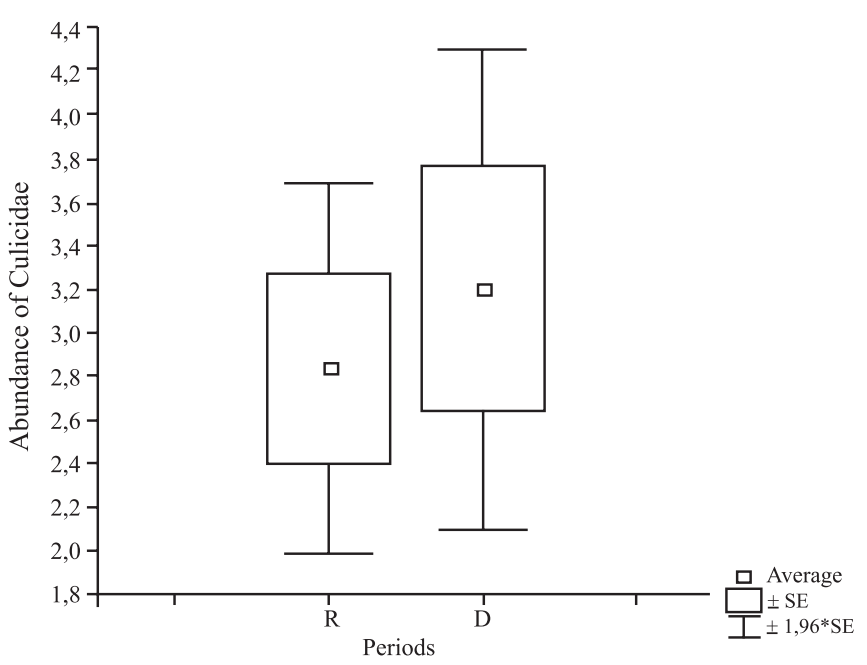

Fig. 3. Comparison between abundance of Culicidae $\{\operatorname{Ln}(x+1)\}$ and seasonal periods where $\mathrm{R}=$ rainy and $\mathrm{D}=$ dry; $(\mathrm{t}=-0.517 \mathrm{p}=0.616)$, in Guzmania brasiliensis in the Reserva Ducke, Manaus, Brazil. 
Table I. Species of Culicidae collected in bromeliads of Guzmania brasiliensis in the dry and rainy periods from 2003 to 2005 in Reserva Ducke, Manaus, Brazil.

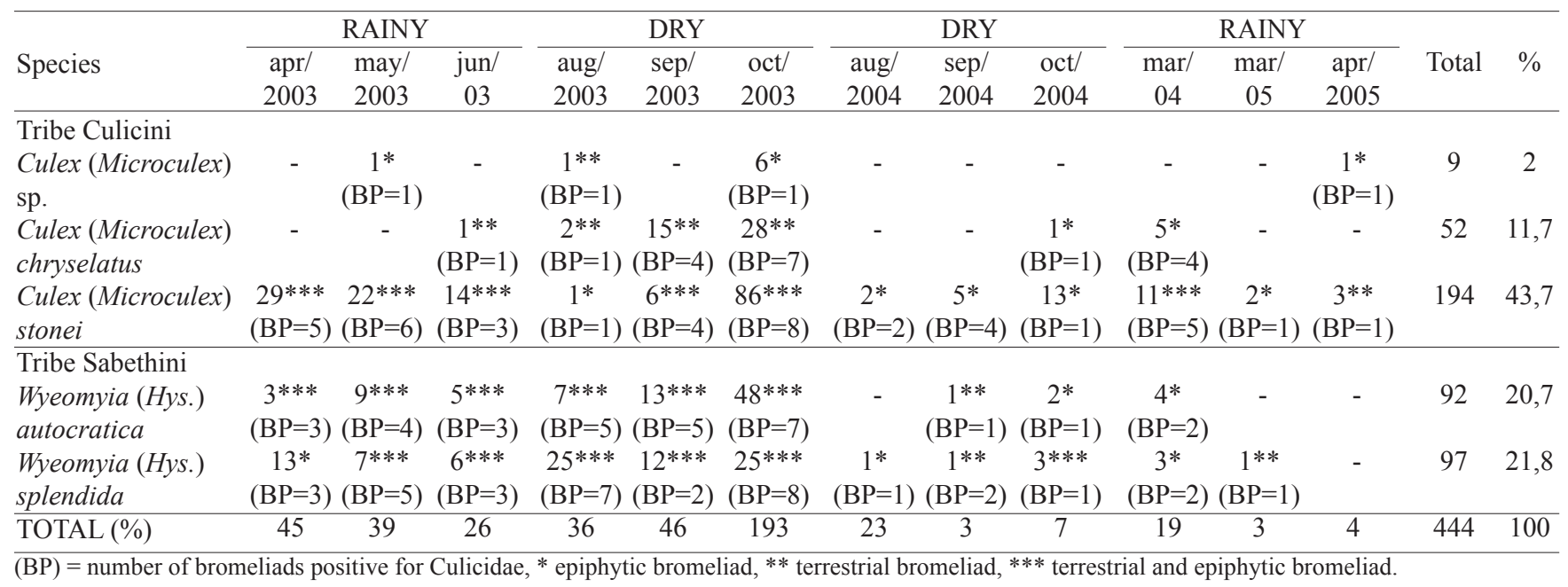

are suggestive of differences between the abundance of culicids and the seasonal periods ( $\mathrm{t}$-test, $\mathrm{t}=-5.517 ; \mathrm{p}=0.616$ ) (Fig. 3). The highest abundance of individuals was found in the dry season in October 2003 (Fig. 2).

These results are similar to those reported by Liria (2007), who found higher numbers of culicids, as well as higher diversity of these organisms, during the dry season in the bromeliads Aechmea fendleri Andre, 1889 and Hohenbergia stellata Schult, 1818 in Venezuela. This author attributed the increase in abundance to the presence of multiple compartments in the plant (lateral foliar tanks) that retain water and debris. Thus, female Culicidae are able to recognize these microhabitats, which are favorable as larval habitat, supporting the hypothesis that species such as Wyeomyia e Culex (Microculex) inhabit the studied plants even in the face of reduced rates of precipitation (Lopez et al. 1998).

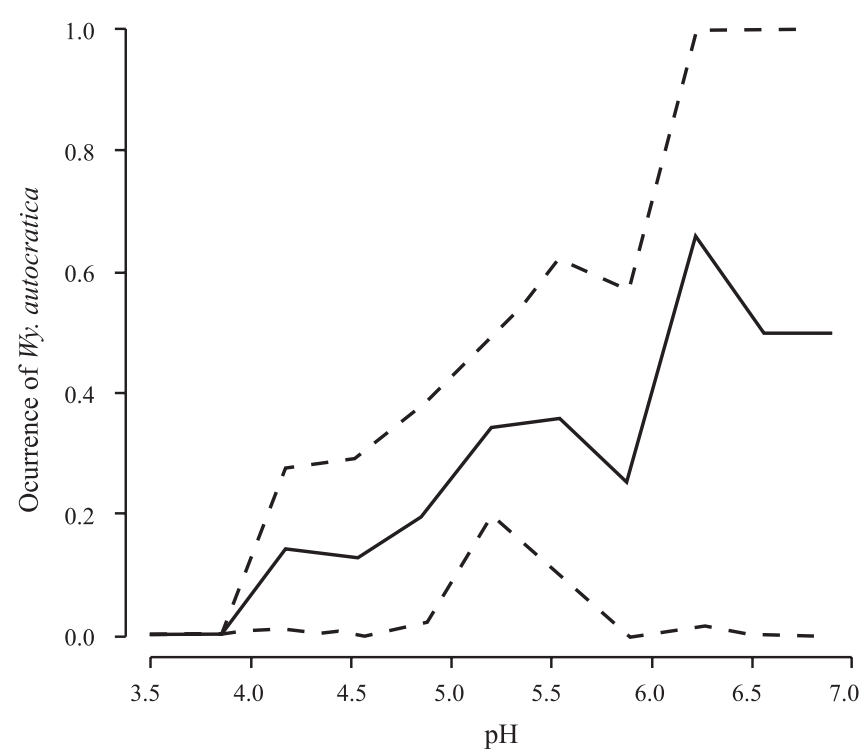

Fig. 4. Relation between $\mathrm{pH}$ and the occurrence of Wyeomyia autocratica collected in Guzmania brasiliensis in dry and wet periods in 2003 and 2005 in Reserva Ducke, Manaus, Brazil. The solid line represents the probability of occurrence and the dashed line represents the confidence interval.
Influence of physical and chemical variables - The volume of water in bromeliads varied from 50 to $450 \mathrm{~mL}$, $\mathrm{pH}$ from 4.6 to 6.9 , electrical conductivity from 10 to $50 \mu \mathrm{S} /$ $\mathrm{cm}$ and the temperature remained approximately $27^{\circ} \mathrm{C}$, as expected for nurseries located in shaded areas as a result of vegetation cover. In general, phytotelmata of bromeliads do not vary greatly in the quality of water in the tanks, so that the physical and chemical characteristics of the water do not change abruptly; there is, however, variation in the quantity of water in the reservoir (Kitching 2000).

Culicidae richness showed no relation to the total abundance of culicids, but rather to the volume of water in the tanks $(\mathrm{p}=0.001)$ (Table II). The abundance of culicids was positively correlated with the volume of water $(\mathrm{F}=8.834$; $\mathrm{p}=$ $0.003 ; r^{2}=0.062$ ), a fact already observed by Lounibos (1983) and Ospina-Bautista et al. (2004).

Two species had their occurence related to $\mathrm{pH}$ (Wy. autocratica e Wy. splendida) (Table III, Figs. 4 and 5, respectively). In bromeliads, the amount of organic matter available in the tank tends to be an essential resource for the occurrence of species, affecting their abundance and richness (Kitching 2000, 2001). Abiotic factors such as $\mathrm{pH}$ and temperature affect the concentration of organic matter in the water (Esteves 1998), thus the volume of water has an indirect effect on the community of Culicidae by means of these abiotic conditions. Another possibility is that the increase in the volume of water also leads to an increase in the occurrence of predators such as Coenagrionidae (Odonata) and Veliidae

Table II. Values of multiple regression relating the richness of Culicidae species to the total abundance of culicids and volume of water $(\mathrm{mL})$ found in Guzmania brasiliensis in the dry and rainy periods from 2003 to 2005 in Reserva Ducke, Manaus, Brazil.

\begin{tabular}{ccccc}
\hline Factor & Estimated & Standard Error & Value of $\mathrm{t}$ & $\mathrm{p}$ \\
\hline Intercept & 0.586 & 0.128 & 4,587 & $<0.001$ \\
Abundance & 0.000 & 0.000 & 0.29 & 0.772 \\
Volume & 0.114 & 0.01 & 11,253 & $<0.001$ \\
\hline
\end{tabular}




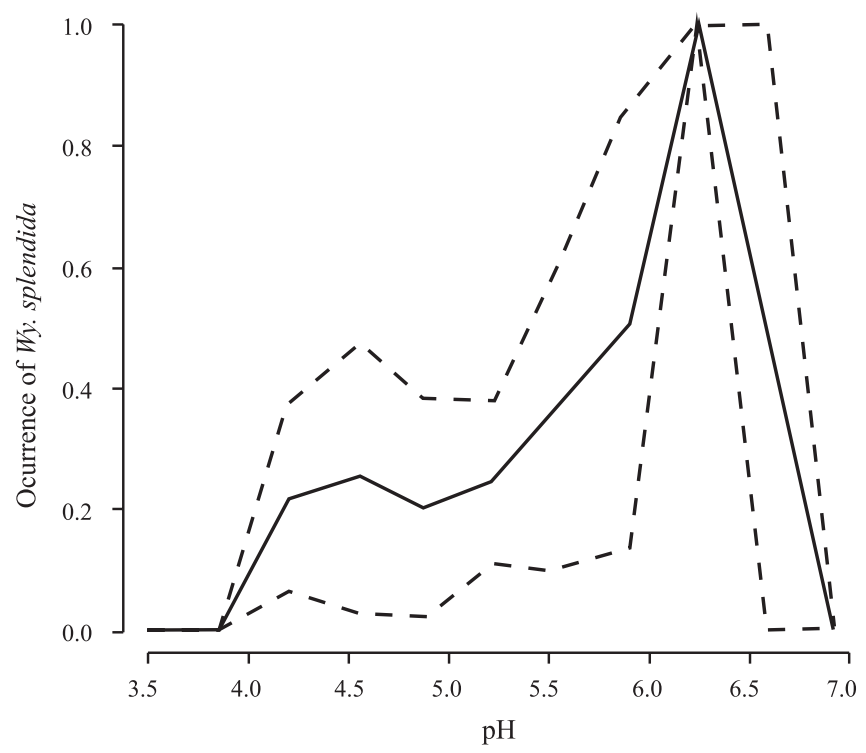

Fig. 5. Relation between $\mathrm{pH}$ and the occurrence of Wyeomyia splendida collected in Guzmania brasiliensis in dry and wet periods in 2003 and 2005 in Reserva Ducke, Manaus, Brazil. The solid line represents the probability of occurrence and the dashed line represents the confidence interval.

(Heteroptera), in addition to other Culicidae predators. This regulates the populations of other species in the same group in bromeliads (Lopes et al. 1985; Furieri 2004), although it is not strong enough to eliminate the positive correlation between abundance and volume, only being able to reduce this effect, as anticipated in the models proposed by Casula et al. (2006).

The weak correlation between abundance of culicids and water body volume can then be explained, not by the increase in space or of alloctonous resources that favor higher growth of culicid populations, but rather by changes in physical and chemical variables, as was found in the species $W y$. autocratica and $W y$. splendida, the occurrence of which is related to $\mathrm{pH}$ (Table III).

Studies related to tolerance in $\mathrm{pH}$ ranges have indicated that some groups show direct responses (Kitching 2000). Exemplifying this, Benzing et al. (1972) showed that bromeliads in the genus Aechmea have their water changed from acidic to alkaline when seaweed cultures are introduced. However, the presence of insect larvae promotes the opposite effect, increasing the $\mathrm{pH}$ of the environment. Paradise (2000) noted the increase of Culicidae females in the presence of Scirtidae larvae (Coleoptera) because the latter act efficiently in the process of decomposition, acidifying the environment or promoting changes in the $\mathrm{pH}$ zones (4.5 to 6.5), reducing the mortality of mosquitoes in tree holes. Therefore, these metabolic responses could be an indication of success resulting from the high degree of specificity that certain insects such as Wy. autocratica and Wy. splendida, as well as other taxa, have established with phytotelmic environments (Kitching 2000).

The bromeliad G. brasiliensis hosted four species of Culicidae. Thus, we may consider these immatures to be important components in the aquatic community present in G. brasiliensis, since the success of the occurrence and
Table III. Values of $\mathrm{p}$ for logistic regressions relating the physical and chemical characteristics of the water with the occurrence of Culicidae species collected in Guzmania brasiliensis in the dry and rainy periods from 2003 to 2005 in Reserva Ducke, Manaus, Brazil.

\begin{tabular}{ccc}
\hline & \multicolumn{2}{c}{ Physical and chemical variable } \\
\cline { 2 - 3 } Species & $\mathrm{pH}$ & Conductivity \\
\hline Culex (Microculex) sp. & 0.1691 & 0.3017 \\
Culex chryselatus & 0.1476 & 0.8173 \\
Culex stonei & 0.9504 & 0.2093 \\
Wyeomyia autocratica & $0.0108^{*}$ & 0.3476 \\
Wyeomyia splendida & $0.0062^{*}$ & 0.0623 \\
* Significant at $\mathrm{p}<0.05$ & &
\end{tabular}

abundance of the species investigated, such as those of the genus Wyeomyia, are associated not only with the quantity of water in the tank but also with abiotic factors such as $\mathrm{pH}$. Probably these factors added to the ability of the plant to retain water and make alloctonous organic resources available to the insect community, promoting a gradual increase in the quantity of culicids, found in the bromeliads Vriesea and Guzmania, where these are factors were responsible for maintaining this microcosm.

Acknowledgments. We thank the PIPT/FAPEAM n ${ }^{\circ} 812 / 04$ and INPA/ MCT - PPI 1-3570 projects for logistical support. The technician Jaílson Vidal and the exhibitioner Janny Fernandes helped in the field collections. A Scientific Initiation scholarship (PIBIC/INPA) was granted to the first author. N. Hamada is a CNPq research fellow. Dr. Monique Albuquerque Motta (FIOCRUZ-RJ) confirmed the identification of Wyeomyia, Carolina S. Nunes translated the manuscript and Embrapa/AM provided meteorological data.

\section{REFERENCES}

Ambruster, P.; R. A. Hutchinson \& P. Cotgreave. 2002. Factors influencing community structure in a South American tank bromeliad fauna. Oikos 96: $225-234$.

Aragão, M. B. 1968a. O ciclo anual dos Anopheles do subgênero Kerteszia no Brasil. Memórias do Instituto Oswaldo Cruz 66: 85-106.

Aragão, M. B. 1968b. Sobre a distribuição vertical dos criadouros de Anopheles do subgênero Kerteszia no sul do Brasil. Memórias do Instituto Oswaldo Cruz 66: 132-144.

Benzing, D. H.; J. A. Deer \& J. E. Titus. 1972. The water chemistry of microcosms associated with the bromeliad Aechmea bracteata. American Midland Naturalist 87: 60-70.

Casula, P.; A. Wilby \& M. B. Thomas. 2006. Understanding biodiversity effects on prey in multi-enemy systems. Ecology Letters 9: 995-1004.

Cerqueira, N. L. 1961. Distribuição geográfica dos mosquitos da Amazônia (Diptera, Culicidae, Culicinae). Revista Brasileira de Entomologia 10: 111-168.

Clastrier, J. 1970. Culex (Melanoconion) dolicopyllus n. sp. et Culex (Microculex) stonei Lane et Whitman, 1943 (Diptera, Culicidae) A Guyane Francaise. Annales de Parasitologie 45: 857-861.

Consoli, R. A. G. B. \& R. Lourenço-de-Oliveira. 1994. Principais mosquitos de importância sanitária no Brasil. Rio de Janeiro, Editora Fiocruz, $228 \mathrm{p}$.

Esteves, F. A. 1998. Fundamentos de Limnologia. Rio de Janeiro, Editora Interciência/FINEP, 601 p.

Forattini, O. P. 1965a. Entomologia Médica. Culicini: Haemagogus, Mansonia, Culiseta, Sabethini, Toxorhynchitini. Arboviroses, Filariose bancrofitiana. Genética. Vol. 1. São Paulo, Editora Universidade de São Paulo, $416 \mathrm{p}$.

Forattini, O. P. 1965b. Entomologia Médica. Culicini: Culex, Aedes, e Psorophora. Vol. 2. São Paulo, Editora Universidade de São Paulo, $506 \mathrm{p}$. 
Forattini, O. P. \& A. Toda. 1966. Notas sobre Culicidae (Diptera). Algumas espécies de Microculex. Studia Entomologica 9: 501-514.

Forattini, O. P. 2002. Culicidologia Médica. Identificação, Biologia, Epidemiologia. Vol. 2. São Paulo, Editora Universidade de São Paulo, $860 \mathrm{p}$.

Frank, J. H. 1983. Bromeliad phytotelmata and their biota, especially mosquitoes, p. 101-128. In: J. H. Frank \& L. P. Lounibos (eds.). Phytotelmata: Terrestrial Plants as Hosts for Aquatic Insect Communities. Medford, Plexus Publishing, 293 p.

Frank, J. H. \& L. P. Lounibos. 1983. Phytotelmata: Terrestrial Plants as Hosts for Aquatic Insect Communities. Medford, Plexus Publishing, $293 \mathrm{p}$.

Furieri, K. S. 2004. Fauna de libélulas bromelícolas: influência da agregação de bromélias no sucesso reprodutivo e aspectos do controle populacional de mosquitos. Masters Dissertation, Viçosa, Universidade Federal de Viçosa, $47 \mathrm{p}$.

Judd, D. D. 1998. Review of bromeliad-ovipositing lineage in Wyeomyia and the resurrection of Hystatomyia (Diptera: Culicidae). Annals of the Entomological Society of America 91: 572-589.

Kaehler, M.; I. G. Varassin \& R. Goldenberg. 2005. Polinização em uma comunidade de bromélias em Floresta Atlântica Alto-Montana no Estado do Paraná, Brasil. Revista Brasileira de Botânica 28: 219-228.

Kitching, R. L. 2000. Food Webs and Container Habitats: The Natural History and Ecology of Phytotelmata. Cambridge, Cambridge University Press, $431 \mathrm{p}$

Kitching, R. L. 2001. Food webs in phytotelmata: "bottom-up" and "topdown" explanations for community structure. Annual Review of Entomology 46: 729-760.

Laessle, A. M. 1961. A micro-limnological study of Jamaican bromeliads. Ecology 42: 499-517.

Lane, J. 1953a. Neotropical Culicidae. Vol. 1. São Paulo, Press in University of São Paulo, 548 p.

Lane, J. 1953b. Neotropical Culicidae. Vol. 2. São Paulo, Press in University of São Paulo, 1112 p.

Leme, E. M. C. 1993. Bromélias na natureza. Rio de Janeiro, Ed. Marigo Comunicações Visuais, 183 p.

Liria, J. 2007. Fauna fitotelmata em las bromélias Aechmea fendleri André y Hohenbergia stellata Schult del Parque Nacional San Esteban, Venezuela. Revista Peruana Biologia 14: 33-38.

Lopes, J.; J. R. Arias \& J. D. Charlwood. 1985. Estudo ecológico da fauna de Culicidae (Diptera) silvestres criando em pequenos de água em mata e em capoeira no município de Manaus - AM. Ciência e Cultura 37: 1299-1311.

Lopez, L. C. S.; A. M. A. D’Elias \& R. R. Iglesias. 1998. Fatores que controlam a riqueza e a composição da fauna aquática em tanques da bromélia Aechmea bromeliifolia (Rudge) Baker, na Restinga de Jacarepiá-Saquarema/RJ. Oecologia Brasiliensis 5: 91-100.

Lounibos, L. P. 1983. The mosquito community of treeholes in subtropical Florida, p. 223-246. In: Frank, J. H. \& L. P. Lounibos (eds). Phytotelmata: Terrestrial Plants as Hosts for Aquatic Insect Communities. Medford, Plexus, 293 p.

Machado-Allison, C. E.; R. Barrera; L. Delgado; C. Gómez-Cova \& J. C. Navarro. 1986. Mosquitos (Diptera: Culicidae) de los fitotelmata de Panarique, Venezuela. Acta Biológica Venezolana 2: 1-12.

Mestre, L. A. M.; J. M. R. Aranha \& M. L. P. Esper. 2001. Macroinvertebrate fauna associated to the bromeliad Vriesea inflate of the Atlantic Forest (Paraná State, Soulthern, Brazil). Brazilian Archives of Biology and Technology 44: 89-94.

Motta, M. A.; R. Lourenço-de-Oliveira \& M. A. M. Sallum. 2007. Phylogeny of genus Wyeomyia (Diptera; Culicidae) inferred from morphological and allozyme data. Canadian Entomologist 139: 591-627.

Müller, G. A. \& C. B. Marcondes. 2006. Bromeliad-associated mosquitoes from Atlantic forest in Santa Catarina Island, southern Brazil (Diptera, Culicidae), with new records for state of Santa Catarina. Ilheringia, Série Zoologia 96: 315-319.

Müller, G. A. \& C. B. Marcondes. 2007. Immature mosquitoes (Diptera: Culicidae) on the bromeliad Nidularium innocentii in ombrophilous

Received 02/07/2009; accepted 03/06/2010

Editor: Mário Antonio Navarro da Silva dense forest of Santa Catarina Island, Florianópolis, Santa Catarina State, southern Brazil. Biotemas 20: 27-31.

Nara, A. K. \& A. C. Weber. 2002. Biologia floral e polinização de Aechmea beeriana (Bromeliaceae) em vegetação de baixio na Amazônia Central. Acta Amazonica 32: 571-588.

Navarro, J. C. 1998. Fauna de mosquito (Diptera: Culicidae) del Parque Nacional Cerro El Copey y nuevos registros para La Isla de Margarita, Venezuela. Boletim Entomológico Venezolano 13: 187-194.

Navarro, J. C.; J. Liria; H. Pinango \& R. Barrera. 2007. Biogeographic area relationships in Venezuela: A Parsiomony analysis of CulicidaePhytotelmata distribution in National Parks. Zootaxa 1547: 1-19.

Neiss, U. G. 2007. Estrutura da comunidade de macroinvertebrados aquáticos associados à Mauritia flexuosa Linnaeus (Arecaceae), fitotelmata, na Amazônia Central, Brasil. Masters Dissertation, Manaus, Instituto Nacional de Pesquisas da Amazônia/Universidade Federal do Amazonas, $79 \mathrm{p}$.

Ospina-Bautista, F.; J. V.Estévez-Varón; J. Betancur, \& E. Realpe-Rebolledo. 2004. Estructura y composición de la comunidad de macroinvertebrados acuáticos asociados a Tillandsia turneri Baker (Bromeliaceae) em um bosque alto andino colombiano. Acta Zoológica Mexicana 20: 153-166.

Paradise, C. J. 2000. Effects of $\mathrm{pH}$ and resources on a processing chain interaction in simulated treeholes. Journal of Animal 69: 651-658.

Pires, J.M. 1974. Tipos de vegetação da Amazônia. Brasil Florestal 5: 4858

Ribeiro, M. N. G. \& J. Adis.1984. Local rainfall variability - a potential bias for bioecological studies in the central Amazon. Acta Amazonica 14: $159-174$.

Ribeiro, J. E. L. S.; M. J. G.Hopkins; A. Vicentini; C. A. Sothers; M. A. S. Costa; J. M. Brito; M. A. D. Sousa; L. H. P. Martins; L. G. Lohmann; P. A. C. L. Assunção; E. C. Pereira; C. F. Silva; M. R. Mesquita \& L. C. Procópio. 1999. Flora da Reserva Ducke: Guia de Identificação das Plantas Vasculares de uma Floresta de Terra-Firme na Amazônia Central. Manaus, Instituto Nacional de Pesquisas da Amazônia (INPA), $816 \mathrm{p}$.

Richardson, B. A.; M. J. Richardson; F. N. Scatena \& W. H. McDowell. 2000. Effects of nutrient availability and other elevational changs on bromeliad populations and their invertebrate communities in a humid tropical forest in Puerto Rico. Journal of Tropical Ecology 16: 167-188.

Rozeboom, L. E. \& W. H. Komp. 1950. A new Microculex elongatus, from Colombia, with notes on the subgenus. Proceedings of the Entomological Society of Washington 3: 147-157.

Silva, A. M.; V. Nunes \& J. Lopes. 2004. Culicídeos associados a entrenós de bambu e bromélias, com ênfase em Aedes (Stegomyia) albopictus (Diptera, Culicidae) na Mata Atlântica, Paraná, Brasil. Iheringia, Série Zoologia 94: 63-66.

Smith, L. B. 1955. The Bromeliaceae of Brazil. Smithsonian Miscellaneous Collection 126: 144-157.

Sunahara, T.; K. Ishizaka \& M. Mogi. 2002. Habitat size: a factor determining the opportunity for enonters between mosquito larvae and aquatic predators. Journal of Vector Ecology 27: 8-20.

Torreias, S. R. S. 2008. Macroinvertebrados associados a Vriesea splitgerberi (Mez) L. B. S. M. \& Pitten. (1953) (Bromeliaceae) em uma floresta de campinarana na Reserva Florestal Adolpho Ducke, Amazônia Central. Masters Dissertation, Manaus, Instituto Nacional de Pesquisas da Amazônia/Universidade Federal do Amazonas, 92 p.

Veloso, H. P.; P. Fontana Junior; R. M. Klein \& R. Siqueira-Jacoud. 1956. Os anofelinos do sub-gênero Kerteszia em relação à distribuição das bromeliáceas em comunidades florestais do município de Brusque, Estado de Santa Catarina. Memórias do Instituto Oswaldo Cruz 54: $1-86$.

Yanoviak, S. P. 1999. Community structure in water-filled tree holes of Panama: effects of hole height and size. Selbyana 20: 106-115.

Yanoviak, S. P. 2001. Container color and location affect macroinvertebrate community structure in artificial treeholes in Panama. Florida Entomologist 84: 265-271.

Zar, J. H. 1996. Bioestatistical Analysis. $3^{\text {a }}$ ed., New Jersey, Prentice Hall. Upper Saddle River, 662 p. 